\title{
Endovascular treatment of a symptomatic isolated infrarenal aortic stenosis
}

\author{
Radu Rogoveanu, ${ }^{1}$ Simon Rajendran, ${ }^{2}$ Michael Lee, ${ }^{3}$ Daragh Moneley ${ }^{1}$ \\ ${ }^{1}$ Department of Vascular Surgery, Beaumont Hospital, Dublin, Ireland \\ ${ }^{2}$ Department of Vascular Surgery, Royal College of Surgeons in Ireland, Dublin, Ireland \\ ${ }^{3}$ Department of Radiology, Beaumont Hospital, Dublin, Ireland \\ Correspondence to Dr Simon Rajendran, simonrajendran@gmail.com
}

\section{DESCRIPTION}

A 72-year-old woman presented with a 10-month history of progressively worsening lower-back pain radiating to both lower limbs. The pain was aggravated by movement severely restricting daily activities. Symptoms were attributed to neurogenic claudication due to spinal stenosis. Pain was managed with analgesia and epidural injections. Worsening symptoms prompted further investigations. Magnetic resonance angiography demonstrated a focal infrarenal aortic stenosis with no evidence of iliac disease or external compression (figure 1). Angioplasty was performed using a 10fr balloon improving vessel calibre (figure 2). Postoperative recovery was uneventful with dramatic improvement in lower-limb symptoms allowing mobilisation with reduced analgesia.

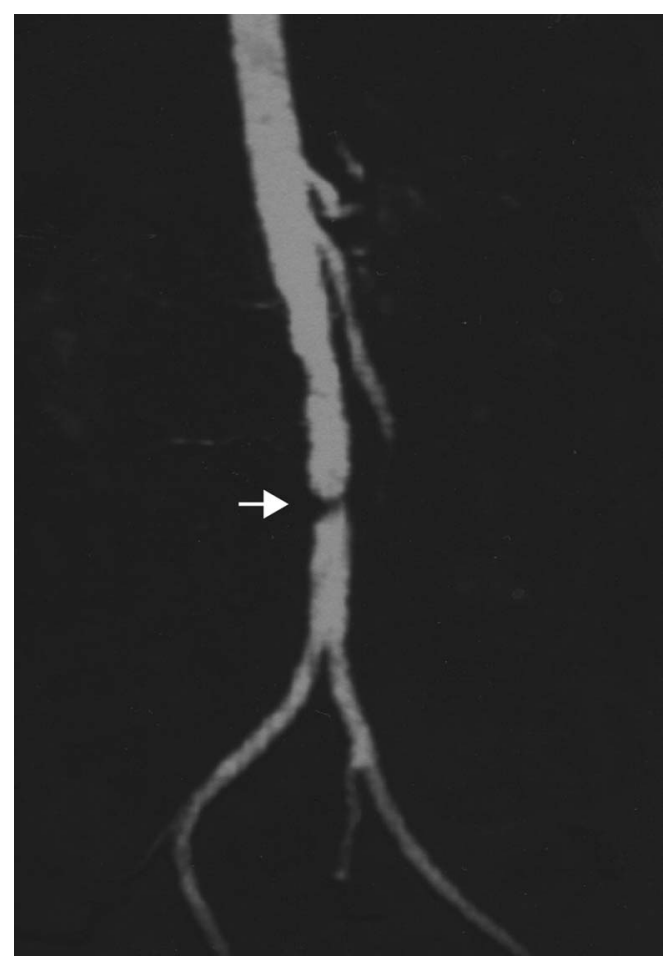

Figure 1 MRA demonstrating focal stenosis on the terminal aorta.
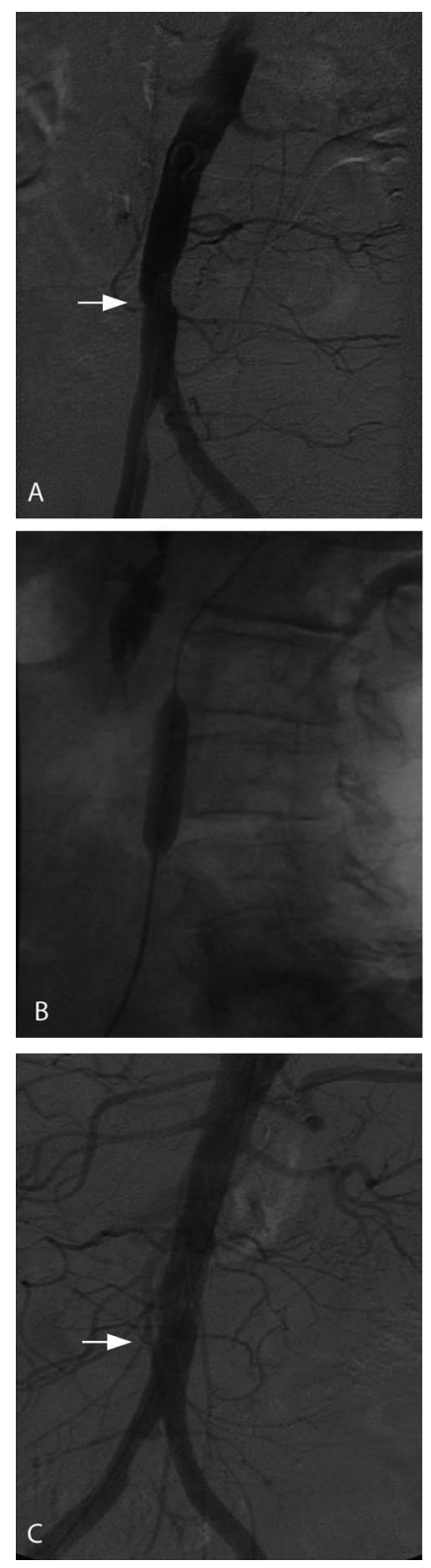

Figure 2 (A) Angiogram showing focal narrowing in the infrarenal aorta (arrow). (B) A 10fr balloon was inserted and angioplasty was performed. (C) Angiogram demonstrating improved calibre following angioplasty. 


\section{BMJ Case Reports}

Isolated infra-renal aortic stenosis is rare and typically presents with claudication symptoms. Presentation with back pain radiating down the legs is unusual. Differential diagnosis includes neurogenic claudication caused by spinal stenosis. Focal aortic lesions are treated by surgical endarterectomy or bypass graft placement. Balloon dilatation or stenting, increasingly being used, ${ }^{1}$ are suitable alternatives to surgery. ${ }^{12}$ Currently, percutaneous transluminal angioplasty has become an important treatment strategy in lesions with little or no iliac disease because it is less invasive, offers good symptomatic relief and is suitable for patients unfit for open surgery. ${ }^{3}$ Failure occurs because of elastic recoil, obstructive intimal dissection or late restenosis, which may require further endovascular intervention or surgery. Furthermore, there is a significant risk of distal thromboembolism. This case highlights the importance of thorough re-evaluation of patients with progressive symptoms and the application of endovascular treatment in selected cases.

\section{Competing interests None.}

Patient consent Obtained.

\section{REFERENCES}

1. Schwindt AG, Panuccio G, Donas KP, et al. Endovascular treatment as first line approach for infrarenal aortic occlusive disease. J Vasc Surg 53:1550-6 e1.

2. Stoeckelhuber BM, Stoeckelhuber M, Gellissen J, et al. Primary endovascular stent placement for focal infrarenal aortic stenosis: long-term results. J Vasc Interv Radiol 2006;17:1105-9.

3. Hallisey MJ, Meranze SG, Parker BC, et al. Percutaneous transluminal angioplasty of the abdominal aorta. J Vasc Interv Radiol 1994;5:679-87.

\section{Learning points}

Thorough clinical assessment is important in patients with progressive disease.

- The lack of predisposing risk factors does not exclude disease.

- Therapeutic attitude is dictated by extent of disease, symptoms and patient factors.

Copyright 2012 BMJ Publishing Group. All rights reserved. For permission to reuse any of this content visit http://group.bmj.com/group/rights-licensing/permissions.

BMJ Case Report Fellows may re-use this article for personal use and teaching without any further permission.

Please cite this article as follows (you will need to access the article online to obtain the date of publication).

Rogoveanu R, Rajendran S, Lee M, Moneley D. Endovascular treatment of a symptomatic isolated infrarenal aortic stenosis. BMJ Case Reports 2012;10.1136/ bcr-2012-007525, Published XXX

Become a Fellow of BMJ Case Reports today and you can:

- Submit as many cases as you like

- Enjoy fast sympathetic peer review and rapid publication of accepted articles

- Access all the published articles

- Re-use any of the published material for personal use and teaching without further permission

For information on Institutional Fellowships contact consortiasales@bmjgroup.com

Visit casereports.bmj.com for more articles like this and to become a Fellow 